\title{
日本と中国の大規模建築プロジェクトにおける品質確保のしくみの比較分析 COMPARATIVE STUDY ON QUALITY ASSURANCE SYSTEM IN LARGE SCALE
BUILDING CONSTRUCTION PROJECTS BETWEEN CHINA AND JAPAN
}

\author{
韓甜*, 金多隆**, 古阪秀三*** \\ Tian HAN, Takashi KANETA and Shuzo FURUSAKA
}

\begin{abstract}
There are a number of international building construction projects operated by Chinese and Japanese stakeholders in China as many of Japanese contractors and developers come to Chinese market in recent years. Quality assurance is an important issue for both Chinese and Japanese construction projects. In China, many accidents have taken place concerning construction projects. As for Japan, though it is assumed to be the highest level in quality assurance, still some severe faults have been found because of its system fatigue. In this paper, the authors compared the quality assurance system between China and Japan by analysis of three large scale building projects operated by Chinese and Japanese stakeholders and located in China and Japan. Organization, procurement, contract, and communication management in the three projects are benchmarked one another. As a result, the characteristics of the quality assurance system in China and Japan are explained through design document, supervision, nominated subcontracts and relationship between general contractors and subcontractors.
\end{abstract}

Keywords: Construction Project, Q uality Assurance, Procurement System, Regulation, Contract, Project M anagement 建築プロジェクト, 品質確保, 発注方式, 法規範, 契約, プロジェクトマネジメント

\section{1.はじめに}

\section{1 研究の背景と目的}

近年，日本の建設業者やデベロッパーの中国進出が増え，同一の プロジェクトを日中の企業が共同で進める機会が多くなっている。 中国は, さまざまな建築物の事故, 欠陥, 瑕疵などの品質問題を抱 えており, 法制度や技術者の資格等の整備により, 品質確保の方策 を模索してきた。他方，日本は相対的に高い品質水準を誇ってきた ものの，依然として品質に関わる事故は発生しており，今後の熟練 技能者数の減少が見込まれる中で, 品質確保のしくみが完成してい るとは言い難い。

本研究は, 日本と中国の大規模建築プロジェクトにおける品質確 保のしくみを比較分析し, それぞれの特徵を明らかにすることを目 的とする。両者の共通点や差異を明らかにすることにより, 両国の 企業による共同のプロジェクトにおいて, いかに品質を確保し，プ ロジェクトを円滑に推進できるかを提示できると考える。

\section{2 研究の方法}

本研究では, 日本と中国で建設された 3 つ建築プロジェクトを 調查し, そこから両国の品質確保のしくみを比較分析した。具体的 な研究の方法は以下のとおりである。
(1)日本と中国における建築プロジェクトの品質確保に関する法規範, 契約約款, 仕様書・規準等を整理し, 建築生産プロセスにおける関 係主体の役割を体系的に示す。(第 3 章)

(2)文献調查およびヒアリング調查により, 調查対象プロジェクトに ついて, 組織図, 組織編成の経緯, 契約関係, 指揮命令系統などの 実態を明らかにする。(第 4 章)

(3)調查結果に基づき, 各プロジェクトで見受けられた日本と中国の 特徵的な差異を分析する。(第 5 章)

(4)上記の知見をもとに, 日本と中国の品質確保のしくみの特徵を整 理し, 考察する。(第 6 章)

\section{2. 既往研究}

中国の建築生産についての報告は文献 1）2）3）4）など，いくつか 見受けられる。木村 5) は中国・台湾・韓国・日本の建築士試験を 比較し, 中国・韓国の「建築法」を照合し, 各国の品質管理体制を 制度的に示している。John Fletcher ${ }^{6)}$ は，大型建築プロジェクトを 成功させる要因として, 企画段階から引渡段階まで予め有効な品質 管理計画を立てられれば，中国の建設プロジェクトの品質レベルは 世界トップクラスに入ることができると指摘している。本研究は,

\footnotetext{
* 京都大学工学研究科建築学専攻 博士後期課程 . 工修

** 京都大学工学研究科建築学専攻 准教授. 博士 (工学)

*** 京都大学工学研究科建築学専攻 教授·工博
}

Grad. Stud., Dept. of Architecture and Architectural Engineering, Kyoto University, M.Eng. Assoc. Prof., Dept. of Architecture and Architectural Engineering, Kyoto University, Dr.Eng. Prof., Dept. of Architecture and Architectural Engineering, Kyoto University, Dr.Eng. 
こうした枠組みが個別のプロジェクトでどのように反映されている か，また日中共同のプロジェクトではどのように調整されているか を検証するものである。中国の個別プロジェクトについては, 王ら 7) が RC 造の外壁構造を中心に設計仕様の比較分析を行っている。 本研究は，こうした構工法（ハード技術）の背景にあるマネジメン ト（ソフト技術）に着目した。

品質確保のしくみに関しては, 高麗ら ${ }^{8)}$ が, 実際の品質事故事 例をデジュール，デファクト，ほころびという 3 つの状態の「記述 モデル」で分析し，日本の建築生産システムの実態とその脆弱性を 明らかにしている。徳田ら 9)10) は, 鉄筋工事・鉄骨工事を対象に, 日本，中国，韓国などの建築プロジェクトにおける品質確保のしく みを比較することによって, 各国が抱える問題を明らかにした。本 研究では，それらの分析方法を援用する。

著者ら ${ }^{11)}$ は, 中国の品質確保のしくみの発展過程を4 段階に分 け, 各段階で 1 つずつの事故事例を取り上げ, 記述モデルで分析し, 各段階の品質確保のしくみ上の問題点を考察した。本研究は, これ を発展させるものである。

\section{3、法制度等による品質確保のしくみ}

日本と中国において建築プロジェクトに関わる法規範，契約約款， 仕様書・規準など（以下，法制度という）のうち主要なものを表 1 に示す。法制度等には, 建築プロジェクト全体を対象とするものと, 設計者・工事監理者や施工者を主な対象とするものがある。

表 1 建築プロジェクトに関わる法制度

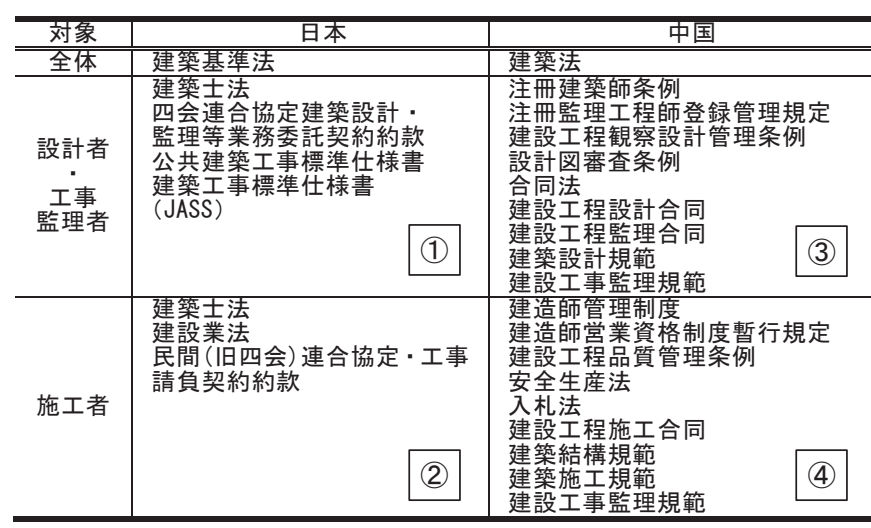

\section{1 日本の建築プロジェクトの品質確保のしくみ}

日本の建築プロジェクトの品質確保のしくみを図 1 に示す。法制 度の丸数字は表 1 に対応する。建築プロジェクトに関わる主体を行 政機関, 発注者, 設計者, 工事監理者, 総合工事業者 (ゼネコン), 専門工事業者（サブコン）とし, 建築生産プロセスを企画, 設計, 工事発注，施工，引き渡しとする。各主体が建築生産プロセスで占 める部分を横棒で表し, 求められる資格がある場合にはそれを記入 した。主体間の主要な情報の流れを実線の矢印, 行為の流れを点線 の矢印で表わす。

企画では発注者が事業計画を立案し，基本計画書を作成する。 発注者は設計段階において「建築士法」,「建築基準法」に従い, 「建築士」資格を有する設計者と契約し, 設計者は「建築基準法」, 「建築士法」を遵守して設計図書を作成しなければならない。設計は
基本設計と実施設計に分けられる。基本設計では発注者の要求や与 条件に基づいて基本設計図書が作成され，実施設計では工事を実施 するために必要な情報をまとめた実施設計図書が作成される。設計 図書の一部である標準仕様書に関しては，通常「公共建築工事標準 仕様書」及び「日本建築学会建築工事標準仕様書」（JASS）を活用 して設計を行う。

建築計画の法適合性について建築確認申請が行われ，「確認済証」 の交付を受けなければ着工できない。

「建築士」資格を有する工事監理者は工事を設計図書と照合し， それが設計図書のとおりに実施されているかいないかを確認する。 なお，工事監理者は設計者と同一でもよい。

施工段階では発注者は「建設業許可」を有するゼネコンに工事を 発注し，そのゼネコンは工事の技術上の管理をつかさどる監理技術 者を現場に配置しなければならない。監理技術者は「一級建築士」 や「一級施工管理技士」等の国家資格を有寸る者等に限られる。

ゼネコンは設計図書をもとに総合図等を作成する。実施設計にお いて, 設計者が「建築工事標準仕様書」及び各社独自の仕様書など を活用しつつ設計図書を完成させる。しかし, ゼネコンが設計者か ら受け取る設計図書の完成度にはプロジェクトによって相当程度の ばらつきがあり, ゼネコンは必要に応じて総合図, コンクリート躯 体図, 平面詳細図等を作成し, それを受けてサブコンが製作図, 加 工図等を作成している。

特定行政庁や指定確認検查機関（行政機関）は施工段階の適切な 時に中間検査並びに工事完了検査を行う。

設計と施工の発注に際しては，それぞれ通常は「四会連合協定建 築設計・監理等業務委託契約約款」, 「民間 (旧四会) 連合協定・工事 請負契約約款」を使って, 設計, 工事監理，施工の契約を結ぶ。た だし，これらの約款は日本で代表的なものではあるが，必ずしもそ れらを使わなくてもよい。

\begin{tabular}{|c|c|c|c|c|c|}
\hline & 企画 & $\begin{array}{l}\text { 設計 } \\
\end{array}$ & 工事発注 & 施工 & $\begin{array}{l}\text { 引き渡し } \\
\end{array}$ \\
\hline \multirow{2}{*}{ 行政機関 } & & & & & \\
\hline & & 建䨄諗 & & 検査 & 検査 \\
\hline \multirow{3}{*}{ 発注者 } & & 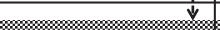 & & 㟧 & 4 \\
\hline & & & & & \\
\hline & 基本計画書 & & & & 検査 \\
\hline \multirow[b]{2}{*}{ 設計者 } & 18 & & & & \\
\hline & & 法制度:(1) & & & 検査 \\
\hline \multirow{2}{*}{ 工事監理者 } & & 設計图 & & 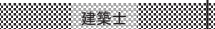 & \\
\hline & & & & 了工事の監璉 & 検査 \\
\hline \multirow{3}{*}{ ゼネコン } & & 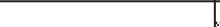 & \pm & $\frac{1}{y}$ & th \\
\hline & & & & 監理拉䢞惺 & \\
\hline & & & & 法制度:(2) 已! 施工の管静 & 検査 \\
\hline \multirow{2}{*}{ サプコン } & & & & $\forall$ & $\dot{\varphi}$ \\
\hline & & & & 法制度:(2) & \\
\hline
\end{tabular}

図1日本の法制度における品質確保のしくみ

\section{2 中国の建築プロジェクトの品質確保のしくみ}

次に, 中国の建築プロジェクトの品質確保のしくみを図 2 に示寸。 表記方法は図 1 と同様である。中国では, 発注者が企画段階におい て,『建築法』に従い, 政府関係部門に建設用地規划許可証や建設工 程規划許可証といった各許可証を申請しなければならない。 


\begin{tabular}{|c|c|c|c|c|c|c|c|}
\hline & 企画 & & 設計 & 工事発注 & 施工 & & 引き渡し \\
\hline \multirow{2}{*}{ 行政機関 } & & & & & & & \\
\hline & 許可証 & 資贊蕃查 & 許可証 & | 資贊蕃查 & 検査 & & 柣查 \\
\hline \multirow{2}{*}{ 発注者 } & & & & & & & \\
\hline & 基本計画書 & & & & & & 検査 \\
\hline \multirow{2}{*}{ 設計者 } & & & 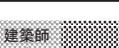 & & & & \\
\hline & & 法制度: & 仓 & & & 指示 & 柆梖 \\
\hline \multirow[t]{2}{*}{ 監理者 } & & & & & $=0$ & & \\
\hline & & & & & 法制度:(3) & 工事の監耕 & 濑查 \\
\hline \multirow{2}{*}{ ゼネコン } & & & & & & & nin' \\
\hline & & & & & 法制度:4 & 施工の管曲 & 検相 \\
\hline \multirow{2}{*}{ サブョン } & & & & & & & 4 \\
\hline & & & & & 法制度: (4) & & \\
\hline
\end{tabular}

図 2 中国の法制度における品質確保のしくみ

設計段階では, 発注者は「建築師」資格を有する設計者と「建設 工程設計合同」という契約を結ぶ。中国の建築生産プロセスでは, 設計は方案設計, 初歩設計, 施工図設計に分けられる。日本の建築 生産プロセスとの差異を図 3 に示す。

\begin{tabular}{|c|c|c|c|c|c|c|}
\hline 澘 & $\begin{array}{c}\text { 企画 } \\
\text { (発注者) }\end{array}$ & $\begin{array}{l}\text { 基本設計 } \\
\text { (設計者) }\end{array}$ & $\begin{array}{l}\text { 実施設計 } \\
\text { (設計者) }\end{array}$ & $\begin{array}{c}\text { 総合図・詳細図 } \\
\text { (ゼネコン) }\end{array}$ & 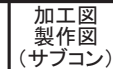 & $\begin{array}{c}\text { 施エ } \\
\text { (ゼネコン) }\end{array}$ \\
\hline 国 & $\begin{array}{l}\text { 企画 } \\
\text { (発注者) }\end{array}$ & $\begin{array}{l}\text { 方案設計 } \\
\text { (設計者) }\end{array}$ & $\begin{array}{l}\text { 初歩設計 } \\
\text { (設計者) }\end{array}$ & $\begin{array}{l}\text { 施工图設計 } \\
\text { (設計者) }\end{array}$ & $\begin{array}{l}\text { 妿儡 } \\
\text { (製ブコン) }\end{array}$ & $\begin{array}{c}\text { 施工 } \\
\text { (ゼネコン) }\end{array}$ \\
\hline
\end{tabular}

（）は各段階の担当者である。

\section{図 3 日本と中国の建築生産プロセスの差異}

方案設計では, 発注者の要求や与条件に基づいて建物の外観, 総 面積, 機能など必要な情報をまとめた図面が作成される。この図面 によって, 政府関係部門（行政機関）に建設工程施工許可証等の各 許可証を申請する。初歩設計では, 各専門分野の設計の総合された 図面, 必要な機械の一覧表, 工事費概算書等が作成される。施工図 設計では，建築設計規範という国家標準に基づいて，設計者が鉄筋 の組立図, 電気設備の配線図等の設計図書と工事予算書を作成する。 ただし，鉄骨工事や鉄筋工事ではサブコンが加工図，製作図等の詳 細図を作成する。それ以外の専門工事の設計図書はサブコンがその まま現場で施工ができる水準まで詳細化されている。設計者が作成 した図面はそのまま現場で使われ，ゼネコンが設計業務に関与する ことはない。ゼネコンは，サブコンの描いた加工図，製作図などを 調整する。施工段階では, 発注者は「建造師」資格者を有するゼネ コンに工事を発注する。通常は契約法である「合同法」に従い，「建 設工程施工合同」という契約を結ぶ。ゼネコンは施工の仕様書であ る「建築施工規範」に従い, 実際の工事を行う。

監理者は設計者と別組織であり，第三者の立場から工事に関与す ることが一般的である。「建設工事監理規範」によれば，監理者は発 注者の代理として, 設計段階から施工段階まで現場に常駐し, コス 卜,工期, 品質などの面から工事を監督する役割が与えられている。 発注者は, 「監理工程師」資格を有寸る監理者と「建設工程監理合同」 という契約を結ぶ。監理者は「建設工事監理規範」に従って工事を 監督する。行政機関は各主体の資質審査, 品質監督及び審査, 確認 を行う。

\section{4. 調査対象プロジェクトにおける品質確保のしくみの実態}

\section{1 調査対象プロジェクトの位置づけと概要}

本章では，建築プロジェクト事例の分析により，品質確保のしく みの実態を考察する。調査対象プロジェクトの概要を表 2 に示す。 比較の条件を揃えるために, いずれも設計施工分離発注方式のプロ ジェクトとし，大規模な超高層オフィスビルを選定した。

プロジェクト1（P 1 ）とプロジェクト 2（P 2）はそれぞれ日 本と中国の法制度等の規制を受けている。プロジェクト 3 （P 3 ） はP 1 の発注者がP 2 のゼネコンと契約して中国で実施したプロジ エクトで, 中国の法制度の規制を受けながらも, 日本の契約制度, 商慣習の一部が適用された。本研究では, P 1 と P 3 の同一発注者 が, 異なる法制度等のもとで, いかに品質を確保すべく工夫したか, P 2 と P 3 の同一ゼネコンが異なる発注者の指示を受けながら, い かに対応したかに注目して分析した。

なお，3つのプロジェクトの工事時期は異なっているが，本研究 の分析に関して時点補正は行っていない。調查対象プロジェクトの 選定に際しては, 研究目的に合致することに加え, 詳細な情報が入 手可能で, ヒアリング調查への協力も得られる相手方の存在も考慮 した。

P 1 の発注者には 2009 年 11 月, 2010 年 3 月, 2013 年 7 月に, P 2 の発注者と施工者には 2010 年 6 月, 2013 年 10 月に, P 3 の施工 者には 2012 年 9 月, 2013 年 7 月にヒアリング調查を行った。また 現地で収集した設計図書（特記仕様書を含む）, 施工計画書, 打合せ 議事録や発注者から公表されている書籍等の文献 注1)も参考にした。

表 2 調査対象プロジェクトの概要

\begin{tabular}{|c|c|c|c|}
\hline & P 1 & P 2 & $\mathrm{P3}$ \\
\hline 建 設 地 & 尧京（日本） & "広州（中国） & 卡海（中国） \\
\hline 数 & 54 階+地下 6 階 & 112 階+地下 5 階 & 101 階+地下 3 階 \\
\hline 延床面積 & 約 38 万 $\mathrm{m}^{2}$ & 約 51 万 $\mathrm{m}^{2}$ & 約 38 万 $\mathrm{m}^{2}$ \\
\hline 期 & $2000.4 \sim 2003.4$ & $2011.8 \sim 2015.11$ & $2004.11 \sim 2008.5$ \\
\hline 入札方式 & 指名競争入札 & 一般競争入札 & 指名競争入札 \\
\hline 発 注 者 & $\begin{array}{c}\text { 再開発組合 } \\
\text { (代表 X社(日本)) }\end{array}$ & $\mathrm{G}$ 社（中国） & $\begin{array}{c}\text { 投資者集団 } \\
\text { (代表 } \text { X 社(日本)) }\end{array}$ \\
\hline 組織規模 & 約 40 名 & 約70名 & 約 80 名 \\
\hline 設 計 者 & $\begin{array}{l}\text { デザイナー：米国 } \\
\text { 建築：日本 } \\
\text { 構造：日本 } \\
\text { 設備：日本 }\end{array}$ & $\begin{array}{l}\text { デザイナー：米国 } \\
\text { 建築：中国 } \\
\text { 構造：中国 } \\
\text { 設備：中国 }\end{array}$ & $\begin{array}{l}\text { デザイナー：米国 } \\
\text { 建築: 米国, 日本 } \\
\text { 構造: 米国, 日本 } \\
\text { 設備: 旦本 } \\
\text { 施工図設計：中国 }\end{array}$ \\
\hline $\begin{array}{c}\text { 工事監理者 } \\
\text { 監理者 }\end{array}$ & 日本企業 & 中国企業 & 中国企業 \\
\hline ゼネコン & 日本企業 JV & Z 社 (中国) & Z 社 JV (中国) \\
\hline
\end{tabular}

注：ここでいう発注者組織の規模は，各プロジェクトの品質確保，管理業務 遂行のための技術者数に限定している。

\section{2 対象プロジェクトの特徵}

\section{2.1 プロジェクト 1 （P 1)}

P 1 は都市再開発プロジェクトである。発注者は再開発組合であ るが，その代表として選任されたX社が，発注者の役割を担った。 P 1 のプロジェクト組織図を図 4 に示す。

\section{(1)P 1 の組織編成の経緯（図 4の実線矢印）}

$\mathrm{X}$ 社は，プロジェクト関与者（デザイナーを除く）をX社と長期 的取引のある者から選定した。設計者は建築, 構造, 設備を個別に 選定し, 内部組織のX社設計部がそれらの間を管理調整した。工事 監理者はX社設計部が担当した。ゼネコンはX社と長期的取引のあ る大手ゼネコンの中から指名競争入札によって 2 社を選定し，これ ら 2 社が JV を構成して契約した。消防, 電気, 空調, 給排水衛生, 


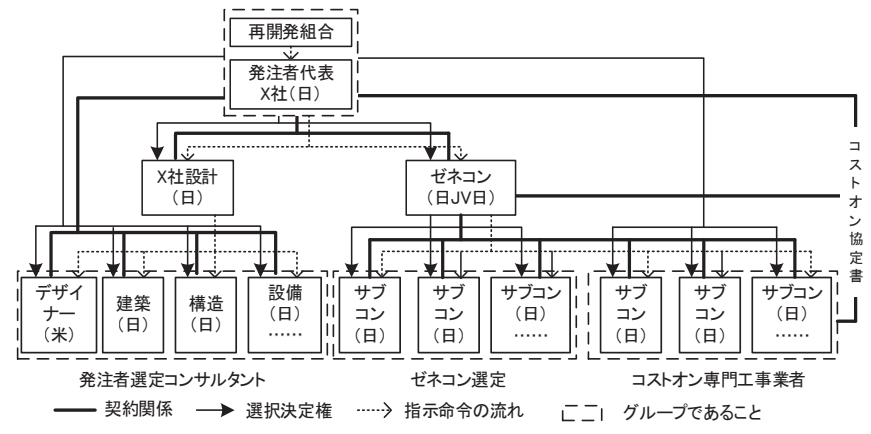

図4Ｐ１のプロジェクト組織図

昇降機, ゴンドラ等のサブコンは, 発注者がコストオン方式で選定 し, 残りのサブコンはゼネコンが選定した。

\section{(2)P 1 の契約関係（図4の実線）}

発注者とゼネコンは，「民間（旧四会）連合協定工事請負契約約 款」に基づいて契約した。発注者はゼネコン並びに電気，空調等の コストオン専門工事業者との三者間でコストオン協定を結んでいる。 その協定書にはコストオン専門工事業者の発注者に対する責任とし て, 完成責任, 品質責任, 瑕疪担保責任が詳しく規定されている。 ゼネコンはゼネコンが選定したサブコンならびにコストオン専門工 事業者と下請負契約を結び, 最終的にはゼネコンの一式請負契約の 形をとっている。

\section{(3)P 1 の指揮命令系統（図 4の点線矢印）}

X社が各設計者およびゼネコンに指示命令を出した。具体的には， 建物の外観及び機能など品質にかかわるものをX社が考慮し, 設計 者に設計変更を指示した。X社設計部は設計者のとりまとめや行政 折衝を行っており, 各設計者が発注者に連絡する場合は, X社設計 部を経由することとした。

コストオン専門工事業者へは, ゼネコンが協定書通りに発注者及 び自らの意図を伝達し, 指示命令を出す。具体的には, 設計におけ る注意点，寸法に関する考慮などがあげられる。コストオン専門工 事業者が発注者に連絡する場合は，ゼネコンを経由する。

(4) P 1 の品質確保のしくみ

P 1 の品質確保のしくみを図 5 に示す。発注者はコストオン専門

\begin{tabular}{|c|c|c|c|c|c|}
\hline & 企画 & 設計 & 工事発注 & 施工 & 引ぎ渡し \\
\hline \multirow{2}{*}{ 行政機関 } & & & & & \\
\hline & & 建篍碓認 & & 検查 & 検查 \\
\hline \multirow{2}{*}{ 発注者 } & & & & & \\
\hline & 基本計画書 & & & & 検查 \\
\hline \multirow{2}{*}{ 設計者 } & & & & 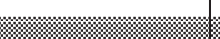 & \\
\hline & & 法制度:(1) 仓 & & & 柣查查 \\
\hline \multirow[t]{2}{*}{ 工事監理者 } & & 設計 & & 䢖慗新 & \\
\hline & & & & 法制度:(1) 已|工事の監璉 & \\
\hline \multirow{2}{*}{ ゼネコン } & & & & 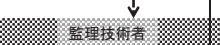 & $\sin 1$ \\
\hline & & & & 法制度:(2) 仓施工の管璉 & 検查 \\
\hline \multirow{2}{*}{ サブョン } & & & & 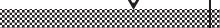 & \\
\hline & & & & 法制度:(2) 已 & \\
\hline
\end{tabular}

図 5 P 1の品質確保のしくみ
工事業者の選定を通じて施工チームに自らの意図を伝達したことに なるが，ゼネコンはこれらを自ら選定したサブコンと共に施工管理 の対象としており，施工チームでの意思疎通が図られている。

\subsection{2 プロジェクト 2 ( $\mathrm{P} 2$ 2)}

P 2 の発注者は香港企業であり，建築プロジェクトの経験が豊富 でないため, 専門の P M 会社 ( $\mathrm{PMr}$ ) を雇って, 企画段階から全体 の管理を依頼した。P 2 のプロジェクト組織図を図 6 に示す。

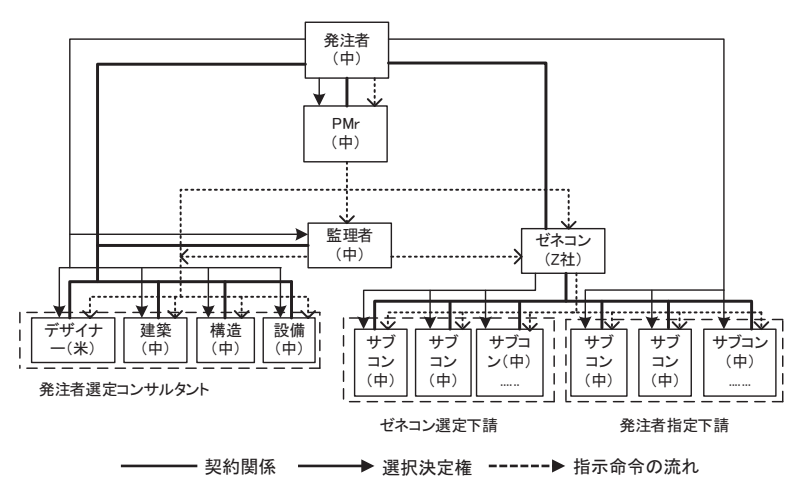

図6Ｐ２のプロジェクト組織図

\section{(1)P 2 の組織編成の経緯（図 6 の実線矢印）}

各設計者は発注者と PMr が特命で選定したが，監理者とゼネコン $\mathrm{Z}$ 社は一般競争入札で選定した。カーテンウォール, 空調, 衛生, 電気設備, 昇降機などのサブコンを発注者が指定した。残りの工種 のサブコンはゼネコンが選定した。

\section{(2)P 2 の契約関係（図6の実線)}

P 2 では, 香港の標準契約約款 注2）が採用された。また, 「建設 工程質量管理条例」第十二条によって, 当該規模のプロジェクトで は第三者の監理者を雇う必要がある。発注者は PMr, 監理者, 各設 計者, ゼネコンと契約を結んだ。発注者の指定したサブコンにはゼ ネコンと下請負契約を結ばせ, 品質責任等はゼネコンが負うことと した。ゼネコンは残りのサブコンとも下請負契約を締結した。

\section{(3)P 2 の指揮命令系統（図6の点線矢印）}

PMr は発注者の代わりに各設計者, 監理者, ゼネコンに発注者の 意図を伝達し，指示命令した。監理者は各設計者とゼネコンに発注 者および PMr の意図を伝達し, 監理契約に基づき, 指示命令した。 ゼネコンは, 自ら選定したサブコンと発注者が指定したサブコンに 発注者と PMr および自らの意図を伝達し, 指示命令した。具体的に は, PMr が発注者の代わりに設計者に建物の外観, 機能などに関し て指示命令したり, ゼネコンに工期の短縮, 工法の改良などに関し て指示命令した。また, ゼネコンがサブコンに工種ごとの工程, 工 種間の調整に関して指示命令した。監理者は, 設計者およびゼネコ ンに対して工事中に問題のある部分に改善要請などを出している。

\section{(4)P 2 の品質確保のしくみ}

P 2 の品質確保のしくみを図 7 に示す。PM r はサブコン以外の設 計者, 第三者監理者 (監理工程師), ゼネコン (建造師)を管理した。 ゼネコンは自ら選定したサブコンと発注者が指名したサブコンを管 理した。監理者は施工段階から P 2 に関与したが, 設計者とゼネコ ンに指示した。 


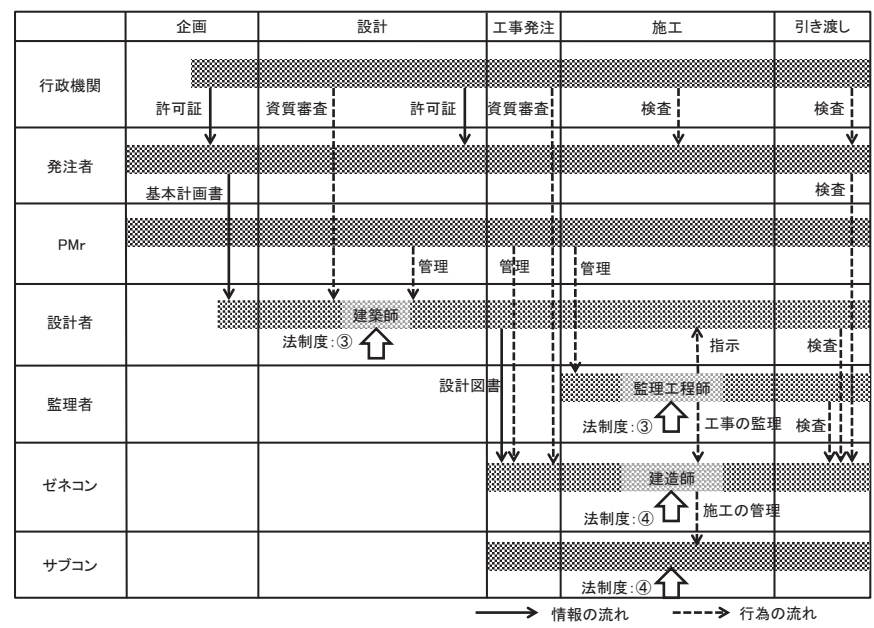

図7 P 2の品質確保のしくみ

\section{2.3 プロジェクト 3 (P 3 )}

P 3 は, 30 数社が新しい投資会社を設立して実施したプロジェク トである。X社が，発注者の代表としてプロジェクトを統括した。 P 3 の組織図を図 8 に示す。

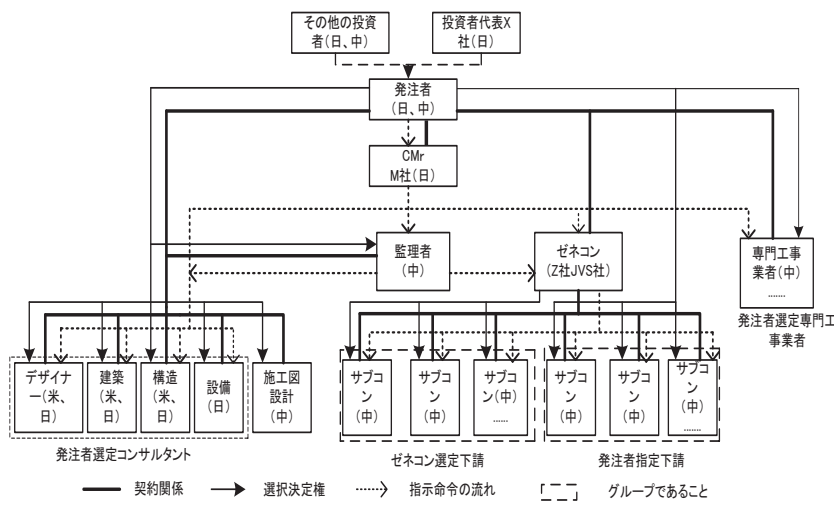

図8P3のプロジェクト組織図

\section{(1)P 3 の組織編成の経緯（図 8 の実線矢印）}

中国では，P 3 の規模に対応する資質注3) を有する日系設計者が 当時は存在しなかったため, 発注者は中国の設計図設計者（詳細は 5.1 節で述べる）から指名競争入札によって設計者を選定した。ま た，P 3 の規模では「特級」資質注4) を有する建設業者が施工しな ければならない。しかし，「特級」を有する日系ゼネコンはなかった ため，発注者は「特級」を有する中国の建設業者の中から高層建築 の施工実績がある業者を指名競争入札によって 2 社（P 2 と同じ Z 社および $\mathrm{S}$ 社）を選定した。また，第三者の監理者と契約した。発 注者は, カーテンウォール, 電気, 昇降機を分離発注し, それ以外 にも空調，衛生などのサブコンを指定した。残りのサブコンはゼネ コンが選定した。

\section{(2)P 3 の契約関係（図8の実線）}

P 3 では中国や日本の標準契約約款ではなく, FIDIC の英語版と 日本語版が用いられた。設計は分離発注であり，発注者がそれぞれ の設計者と契約を結んだ。また，発注者は監理者，ゼネコンおよび 分離発注した専門工事業者と契約を結んだ。一方で，発注者は指定
したサブコンとは直接契約を結ばず, 事前にゼネコンと協議した上 で, ゼネコンに契約を結ばせた。発注者指定下請の完成責任・品質 責任・瑕疵担保責任は, ゼネコンが負った。この点は P 1 のコスト オン専門工事業者と大きく異なる。ゼネコンは自ら選定したサブコ ンと下請負契約を結んだ。

\section{(3)P 3 の指揮命令系統（図 8 の点線矢印)}

発注者が各設計者，第三者監理者，ゼネコンに自らの意図を伝達 した。通常は，発注者がサブコンに直接指示することはないが，P 3 では分離発注の専門工事業者に発注者が直接意図を伝達し, 指示 命令した。ゼネコンが選定したサブコンと発注者指定下請は，いず れも契約通りにゼネコンの指示命令に従わなければならないとした。 具体的には，発注者が設計者に建物の外観，機能などに関して指示 命令したり, ゼネコンに工期の短縮, 工法の改良などに関して指示 命令した。また，ゼネコンがサブコンに工種ごとの工程や工種間の 調整に関して指示命令した。

\section{(4)P 3 の品質確保のしくみ}

P 3 の品質確保のしくみを図 9 に示寸。発注者は徹底した全数検 查を実施させたほか，工期厳守のための課題解決をゼネコン任せに せず，発注者・監理者も参加して共同で解決した。また，通常はサ ブコンからゼネコンに報告するのに対し，P 3 では，発注者指定下 請はゼネコンを経由せずに直接発注者に報告した。これによって, 意思決定に時間を要した。ゼネコンは二重指示を避けるために, 発 注者とサブコンとの三者会議を開き，詳細なことまで発注者に報告 することにした。P 2 と同じく, 監理者は施工段階から関与したが, 工事中に設計者とゼネコンに指示した。

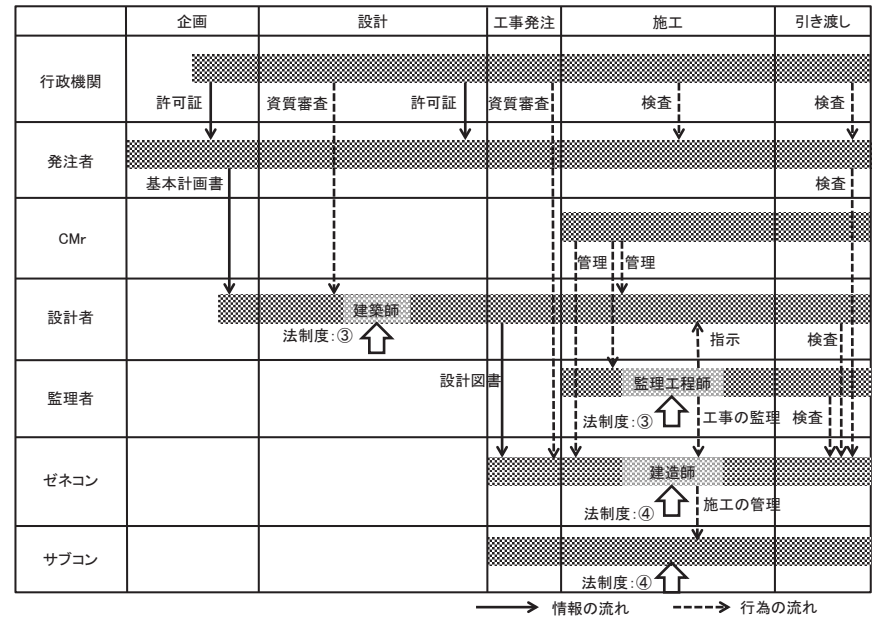

図 9 P 3の品質確保のしくみ

\section{5. 調査対象プロジェクトでの特徵的な差異}

本章では，調查対象プロジェクトで見受けられた，日本と中国の 品質確保に関わる特徵的な差異を，(1)設計図書一の意識の差異，(2) 第三者監理と工事監理, (3)コストオンと指定下請, (4)元請下請関係 に絞って述べる。

\section{1 設計図書への意識の差異}

日本と中国の最も大きな違いは，ゼネコンが図面を描くか描かな いかである。P 1 では，ゼネコンが総合図を描き，各工種の作業順 序を決め, 最も合理的な工程計画を策定してから工事に進んでいた。 
しかし，P 2 では，設計者もゼネコンも総合図は描かず，設計者が 完成させた図面をそのまま現場で使うため, 施工中に各工種の作業 順序が逆転することすらあったという。また，あまりにも設計図の 完成が遅れるので, ゼネコン自らが図面を描くようになったという 事実もある。

P 3 では発注者が日本，ゼネコンが中国ということで，その間で 設計図書に関する認識の差異に起因するトラブルが生じている。一 例を挙げると, 屋上平面図において, 四方の立上りの防水工事の内 容が同じであり，1方向の断面図だけを作成した図面をゼネコンに 渡したところ，他の 3 方向は防水せずと判断した。中国では，四方 同じ内容でも, 四方全ての断面図を省略せずに作成する必要がある。

また，P 3 では初歩設計段階の設計図書で蛇口の高さが $1000 \mathrm{~mm}$ と設計されていたが，施工図設計段階でタイルの目地高さが $1200 \mathrm{~mm}$ と判明すると, 発注者はコストを追加してでも, 蛇口の位 置を $1200 \mathrm{~mm}$ に調整するよう指示した。納まりにこだわる価值観の 違いである。

\section{2 第三者監理と工事監理}

P 1 では，工事監理者は設計者と同じ組織のX社設計部であった。 一方，P 2 と P 3 では第三者監理が採用されている。中国の第三者 監理者は, 設計者と別組織であり, 発注者の代理としてプロジェク トの品質, 工期およびコスト等の面を監理する。第三者監理者は設 計段階から関与することが原則で, 特に施工段階では設計図書通り に工事が進んでいるかいないか, 現場を監理し, 場合によって工事 を止めさせるなど強い権限が与えられている。しかし, P 2, P 3 では, 第三者監理者は施工段階でのみ工事に関与しており, 設計段 階の設計図書などに関する監理業務は行っていない。P 2 の監理者 は発注者の指示通りに業務を遂行していたため, 設計者の設計図書 の提出遅れ，ゼネコンの工期遅延等の問題が発生した際にも，設計 者とゼネコンに直接指示を出すことなく, 発注者にその状況を報告 し, 発注者の指示を受けて, そのまま設計者とゼネコンに指示した。 この結果, 設計者とゼネコンが監理者を無視し, 発注者の指示を直 接受け，監理者がサインを求めるような問題が発生した。

P 3 では, 発注者とゼネコンの間で設計図書の完成度についての 認識の違いがあり, 監理者の関与が施工段階からであったため, よ り早い段階で発注者に有効な助言ができず，設計者に設計図書に関 する指示もできなかった。結局，施工段階においても，実際には発 注者と設計者の間で設計図書に関する直接のやり取りが多く, 監理 者は法的に必要となる限定的な承認印の押印に終始している。

P 2 と P 3 において監理者の果たす役割は，例外的なものではな く, 中国の他のプロジェクトでも現れている。監理者の権限および 役割に関する検討はこれからの中国の大きな課題と考えられる。

\section{3 コストオンと指定下請}

P 1 ではコストオン専門工事業者が発注者により選定され，P 2 と P 3 では指定下請業者が発注者より選定された。コストオンと指 定下請の違いを表 3 に示す。発注者に対する完成責任・品質責任・ 瑕疪担保責任をゼネコン，サブコンいずれか負うかが，コストオン と指定下請で大きく異なる ${ }^{12)}$ 。コストオンでは後者が負い，指定 下請では前者が負う。また, 協定書の有無も両者の違いである。

P 1 では，X社がゼネコン並びに各コストオン専門工事業者と長 期的取引関係にあり, 両者とも信頼関係が深く, 品質を確保するた
表 3 コストオンと指定下請の違い

\begin{tabular}{l|c|c}
\hline & コストオン & 指定下請 \\
\hline \hline 協定書 & あり & なし \\
\hline 発注者との契約 & なし & なし \\
\hline ゼネコンとの契約 & あり & あり \\
\hline サブコンの完成責任, & あり & なし \\
品質責任, 瑕疵担保責任 & & \\
\hline
\end{tabular}

めに三者協定でコストオン専門工事業者を選定した。

P 2 では，発注者に建設プロジェクトの経験がそしく，品質確保 およびコストを考慮して指定下請業者を多く採用した。また，中国 では発注者とゼネコンとの取引関係の有無にかかわらず，カーテン ウォール, 空調, 衛生, 電気, 昇降機などの設備関係のサブコンは 発注者が指定することが一般的である。

P 3 では，X社が初めて中国のゼネコンと取引をするため，ゼネ コンとの信頼関係がなく，P 1 のようにすべてをゼネコンに任せる ことができず, 品質を確保するために, やむを得ず設備関係の工種 を中心にサブコンを指定することにした。

\section{4 元請下請関係}

P 1 において，ゼネコンが選定したほとんどのサブコンは，当該 ゼネコンの協力会に属している。協力会の存在は日本独特のものと 言われている。端的な存在理由は, サブコンにとって継続的に受注 を確保でき経営が安定化すること, ゼネコンにとっては優秀なサブ コンを配下に確保できることがある。この傾向はとび工，鉄筋工， 型枠大工など労務系のサブコンに強い。また, ゼネコンと協力会の サブコンとの間では，書面や協議を介することなく，以心伝心的な コミュニケーションが行われている。とりわけ，労務系の職種にお いて顕著である。このような関係によって長期的取引が行われ，両 者の信頼関係，さらには同じ協力会のメンバー間には，仲間意識と 相互依存的行動が存在している ${ }^{13)}$ 。

日本のある大手建設会社の協力会の会則によれば，協力会の設立 目的は「親睦を密にし, 福祉増進並びに建設技術の向上と品質確保, 工事の安全促進, 円滑なる運用を行い, 事業発展に寄与し共存共栄 を図ること」 ${ }^{14)}$ となっている。これによって, ゼネコンは, サブコ ンを選定するとき, 品質確保のために自らの協力会メンバーから選 ぶことを優先してきた。

P 2 と P 3 においては，日本の協力会のようなものはない。Z Z 社 が選定したサブコンは初めて契約したものが多く，また，同じ企業 集団に属していても競争関係の立場にあるため, サブコン間の連携, コミュニケーション, 技術向上を図るのは難しいと考えられる。

\section{6. 日本と中国の品質確保のしくみの特徵}

実際のプロジェクトP 1 P P の特徴的な差異を分析した結果 から，その背景にある日本と中国の品質確保のしくみの特徵を相対 的に比較すると，以下のようにまとめることができる。

\section{1 日本の品質確保のしくみの特徴}

(1)相互信頼に基づく簡略化された商慣習によって，長期的取引が 維持されている。例えば，P 1 では，発注者とゼネコンの間および ゼネコンとサブコンの間に長期的な取引が維持されていることはそ の証左である。

(2)発注者が直接工事に関与することは少なく, ゼネコンにすべて 任せることが多い。例えば, 発注者組織の要員が P 1 では 40 人程度, 
P 3 では 80 人であり, 規模の相違を考慮しても明らかにP 3 では多 くの要員を必要としている。また, 細かな例であるが, P 3 では発 注者が建物の納まりを美しく仕上げるために, コストを追加しても 蛇口の位置を変更したことなどもその証左である。

(3)ゼネコンの能力が高く, 総合図などを描くことによって, 設計 と施工をうまく繋ぐことができている。また, ゼネコンの協力会と いう日本特有な組織があり, サブコン間の連携, 技術交流, 情報交 換などによって, ゼネコンへの貢献ができ, 高い施工能力につなが っている。例えば, P 1 では, 5.4 で述べたように, 以心伝心的な コミュニケーションが行われているため, 技術向上に貢献がある証 左とみられる。

以上をまとめると, 日本では各主体間の横のコミュニケーション などのつながりが強く, また, 縦の指示命令などのつながりも取れ ており, 品質確保のしくみにおいて問題が発生しやすいところを相 互補完している。これによって, 日本では高い品質確保の水準が維 持されていると考えられる。

\section{2 中国の品質確保のしくみの特徵}

(1)相互信頼に基づく商慣習が築かれていないため, 発注者が品質 確保のためにできるだけ工事の隅々まで関与する習慣がある。発注 者が常に優越的地位にあり, 監理者, 設計者, ゼネコンに強引とも 取れる指示をしたり, 指定下請をしたりすることが数多く発生して いる。P 3 では, 日本の発注者と中国のゼネコンがはじめて請負契 約に基づいて工事を実施したため, 当該発注者がプロジェクトに通 常より多くの要員を導入し, また, 直接かつ梁くプロジェクトに関 与したため, 重装備なプロジェクト組織となり, 意思決定に要する 時間と量をより多く必要とした。

(2)第三者監理制度があるものの，実際には，監理者の権限がうま く発揮できない状況にあり，5.2 で述べたように，設計者とゼネコ ンが監理者を無視して発注者の指示を直接受けたり，監理者は法的 に必要な限定的な承認印の押印に終始したりする事態が発生した。

(3)ゼネコンを支援する組織が存在しておらず，ゼネコンとサブコ ン, 各サブコン間の連携, 技術交流, 情報交換などがない。また, P 2 のように同一ゼネコンの支店間で同じ地域で受注競争をするな ど, 協調的関係の構築とは逆に, 過当競争の傾向がある。

以上をまとめると, 中国では縦のつながり, とりわけ発注者の権 限が強いのに対して, 横のつながりが弱い。これが品質確保のしく みにおいて不安定要因となり, ひいては中国で品質事故が多発する 原因の一つになっていると考えられる。

\section{7. まとめ}

本研究では, 日本と中国の大規模建築プロジェクト事例における 品質確保のしくみを組織編成, 契約関係, 指揮命令系統等の観点か ら比較分析した。調查対象の数は限定的であるが，本研究では第 3 章で法制度に関して一般的な共通事項を整理し, 第 4 章ではそれぞ れの特徴を別途裏付ける文献やヒアリング調查等で補強し, 第 5 章 と第 6 章では過去の調查研究の知見にも基づいている。

日本と中国の品質確保のしくみは，いずれのプロジェクトにおい ても外形的には確立されており, 個別の改善点はあるとしても全体 的な体系に致命的欠陥はない。しかし, 設計図書に対するゼネコン の関与, 監理の概念, 下請選定や元請下請関係といった観点で分析
すると, 両国には 6 章に述べたような有意な差異があり, それが両 国において品質確保のしくみを特徵づけていることが明らかになっ た。

ただし, 品質確保のしくみが各プロジェクトにおいてうまく機能 するためには, 本研究で扱った法制度, 組織等の枠組み以外に, 潜 在的な要因が寄与しているのではないかと考えられる。

今後は, さらに事例を増やして検証するとともに, 品質確保のし くみに影響する要素, 特に法制度による垂直的統制と協力会のよう な水平的連携といった軸から分析し, 両者のバランスがどうなって いるのか，また，プロジェクト全体のマネジメントに活かされてい るのか,より詳細な検討を行いたい。

\section{謝辞}

本研究には調查対象プロジェクトの多くの関係者の方々のご協力 をいただいた。記して謝意を表したい。また, 本研究は日本学術振 興会科学研究費補助金基盤研究 $\mathrm{A}$ 課題番号 23246105 「建設プロジェ クトの発注・契約方式と品質確保のしくみに関する国際比較研究」 （代表者：古阪秀三）の助成を受けている。

注

注 1 ）プロジェクトの固有名称を開示しない条件で調查したため，公表され ている文献であっても「参考文献」には示していない。

注 2 ）香港の標準契約約款は英国の標準契約約款に基づいて作られたもので ある。中国大陸で使用されている標準契約約款よりも細かい記載があるが, 中国大陸の法制度も満たしているため, 香港系の建設業者が中国大陸で事 業を行う際には, 一般的に香港の標準契約約款が採用されている。

注 3 )「建築工程設計資質分級標準」によれば，建築面積 8 万 $\mathrm{m}^{2}$ 以上のプロ ジェクトは「特級」規模であり，「甲級」資質を有する設計者が設計をしな ければならない。

注 4 ）「建築業企業資質等級標準」によれば，高さ $240 \mathrm{~m}$ 以上，および工事費 5000 万元以上のプロジェクトは「特級」資質を有する施工者が施工しなけ ればならない。

\section{参考文献}

1）富樫穎, 岡田知子 : 建築生産システムに関寸る日中比較研究（その 1) 中国の建設業と設計・監理業務の問題点, 大阪市立大学生活科学部紀要, Vol.37, pp.151-159, 1990.3

2) R.Y. Li, 岡田知子, 富樫頴: 建築生産システムに関する日中比較研究 (そ の 2) 中国建設業の改革とその問題点, 大阪市立大学生活科学部紀要, Vol.38, pp.147-154, 1991.3

3）第 8 回アジアコンストラクト会議カントリーレポート（中国），建設経 済研究所, 2002.11.5

4) Ping Yung, Brenda Yip: Construction quality in China during transition: A review of literature and empirical examination, International Journal of Project M anagement, 28, pp.79-91, 2010

5）木村正彦：東アジア（中国・台湾・韓国）における建築業界の構造と建 築品質管理の体制, 日本建築学会第 24 回建築生産シンポジウム論文集, pp.1-8, 2008

6）John Fletcher: 中国大型建設項目的質量管理和項目管理～国際著名工程 管理専門談成功建設高質量項目的関鍵因素～, 化工建設工程, 第 23 巻 第 2 期，pp.10-11，2001

7）王希慧，松村秀一，木本健二，魏慧咷：中国の建築生産システムの特徴 と問題点に関する考察, 日本建築学会第 19 回建築生産シンポジウム論 文集，pp.29-36，2003

8）高麗一大，古阪秀三，金多隆，平野吉信，江頭知幸：品質事故事例から みる建築生産システムの実態とその脆弱性, 日本建築学会計画系論文集, Vol.73, No.623, pp.183-190, 2008.1

9）徳田顕, 吾川正明, 平野吉信, 古阪秀三 : 日中韓台の建築プロジェクト における品質確保のしくみに関寸る国際比較〜鉄筋工事・鉄骨工事にお ける設計・施工内容の決定プロセスを例に〜，日本建築学会第 26 回建 
築生産シンポジウム論文集，pp.27-34，2010.7

10）古阪秀三: 日中韓台の建築プロジェクトにおける品質確保のしくみに関 する比較研究〜鉄筋工事・鉄骨工事を例に〜, 総研リポート, 第 7 号, pp.7-18, 建設物価調查会総合研究所, 2012.5

11）韓甜, 古阪秀三, 李玥 : 中国の建設事故からみる品質確保のしくみの変 遷と実態, 日本建築学会計画系論文集, Vol.79, No.695, pp.173-181, 2014.1

12）日本建設業連合会制度委員会・CM等発注多様化対応部会：コストオ ン・指定下請工事及び性能発注に関する実態調査報告書, 2013.3

13）古阪秀三，橋本貴史，金多隆：日本の建築生産システムの特性に関する 研究（1）専門工事業者の企業行動と協力会に対する意識, 日本建築学 会第 15 回建築生産シンポジウム論文集，pp.125-132，1999

14）清水建設全国連合兼喜会会則, 1982 


\section{COMPARATIVE STUDY ON QUALITY ASSURANCE SYSTEM IN LARGE SCALE BUILDING CONSTRUCTION PROJECTS BETWEEN CHINA AND JAPAN}

\section{Tian HAN*, Takashi KANETA** and Shuzo FURUSAKA***}

* Grad. Stud., Dept. of Architecture and Architectural Engineering, Kyoto University, M.Eng.

** Assoc. Prof., Dept. of Architecture and Architectural Engineering, Kyoto University, Dr.Eng.

*** Prof., Dept. of Architecture and Architectural Engineering, Kyoto University, Dr.Eng.

There are a number of international building construction projects operated by Chinese and Japanese stakeholders in China as many of Japanese contractors and developers come to Chinese market in recent years. Quality assurance is an important issue for both Chinese and Japanese construction projects. In China, many accidents have taken place concerning construction projects. As for Japan, though it is assumed to be the highest level in quality assurance, still some severe faults have been found because of its system fatigue.

In this paper, the authors compared the quality assurance systems between China and Japan by analysis of three large scale building projects operated by Chinese and Japanese stakeholders and located in China and Japan. Organization, procurement, contract, and communication management in the three projects are benchmarked one another. As a result, the characteristics of the quality assurance system in China and Japan are explained through design document, supervision, nominated subcontracts and relationship between general contractors and subcontractors.

The quality assurance systems in Japan:

1. In building construction project in Japan, the parties trust each other by long-term working relationships.

2. The ability of general contractors is excellent. Moreover, the cooperation associations of general contractors, which are thought as peculiar organizations in Japan, have improved the ability of general contractors.

3. The site conference system makes employees have better communication, which improves the ability of the employees.

4. Long-term employment system, which cultivated the quality assurance system.

The quality assurance system in China:

1. In China, the parties cannot trust each other unlike in Japan. So the clients have to participate in the project as much as possible.

2. The authorities and the responsibilities of Chinese supervisors and clients are not classified definitely. Therefore, the Chinese supervisors cannot show their ability clearly.

3. The site conference system cannot make employees have better communication.

4. There is no long-term employment system in China, which makes the quality assurance system instability.

In the future study, the authors will carry out some analysis on which elements can influence the quality assurance system from construction management. 